https://doi.org/10.31470/2706-7904-2021-16-308-312

\title{
COMPARING ACCOUNTS OF ENGLISH WH-QUESTIONS ACQUISITION \\ BY MONOLINGUALS AND BILINGUALS \\ UNDER VARIOUS CONDITIONS
}

Порівняння інтерпретацій засвосння англомовних спеціальних питань монолінгвами і білінгвами в різних умовах

\author{
Leonid Chernovaty \\ Doctor Science in Pedagogy, Full Professor \\ V.N.Karazin Kharkiv National University (Ukraine) \\ leonid.m.chernovaty@meta.ua \\ https://orcid.org/0000-0003-3411-9408 \\ Natalia Kovalchuk \\ PhD in Pedagogy, Associate Professor \\ V.N.Karazin Kharkiv National University (Ukraine) \\ kovalnatalya@bigmir.net \\ https://orcid.org/0000-0002-9483-4297
}

\begin{abstract}
The comparison of English wh-questions acquisition by monolinguals, bilinguals and EFL learners showed inter-groups similarities, which included wh-questions formulaic use, overgeneralization, non-inverted structures, archiforms, double marking of auxiliaries and past tense. The authors suggest a special role of there is/are structures in the wh-questions acquisition by EFL learners. The research results allow assuming the impact of universal factors upon the process of wh-questions acquisition irrespective of the learners' age, onset of the bilingualism, if they acquire English as the first or the second language, or whether it is acquired in the formal or informal environment.
\end{abstract} acquisition.

Key words: bilinguals, EFL learners, monolinguals, universal factors, wh-questions

\section{Introduction}

Bcmyn

Though the process of language acquisition has been intensively researched, the psychological mechanisms underlying the development of the learners' speech inner rules remain unclear. This equally applies to the acquisition of morphology and syntax, specifically to wh-questions. 
There have been quite a lot of studies concerning this problem. In particular, the analysis of irregular past tense utterances in the spontaneous speech of 83 childrenmonolinguals (Marcus et al., 1992) proved that both adults and children memorize irregular verb forms as separate lexemes, while the use of regular verb forms is based of on the internal rule. The impact of this rule is blocked in the process of the irregular past tense forms retrieval. However, the deficiency of this blocking mechanism in children results in the interference between regular and irregular verb forms, as well as in errors related to the retrieval of the latter. It is usually regarded as an argument in favour of the overgeneralization mechanism.

The longitudinal analysis of one subject's speech within the range from two to four years of age (Rowland \& Pine, 2000) focused on the developmental errors related to whquestions use and the subject-auxiliary inversion. According to its findings, correctly inverted $w h$-questions are registered in the learners' speech even before the formation of the internal subject-auxiliary inversion rule due to the formulaic acquisition of certain structures frequently heard in the input.

Two concurrently done studies, both based on the Brown corpus analysis, brought conflicting results. One of them (Rowland \& Pine, 2003) suggested the idea that the duration of transition from the non-inverted wh-questions to the inverted ones depends on the frequency of correct structures in the input, while the other one (Van Valin, 2002) provided a different explanations.

In the experiment with 29 children-monolinguals (aged 2;6 to 3;2) (Valian \& Casey, 2003), the subjects were divided into three treatment groups, where the procedure was based on the quasicontrol condition in the first one, the modelling reception - in the second, and the implicit correction- in the third. The researchers found that even a small amount of input may be enough for the rapid subconscious extraction and generalization of syntactic regularities underlying the question structures of this type. However, this input should be concentrated, varied and presented so that the learner attends to it and attempts to parse it.

In another experiment (Ambridge et al., 2006) the authors investigated the acquisition of non-subject $w h$-questions by 28 monolingual children aged 3;6-4;6. The experiment focused on the elicitation of the structures with four question words (what, who, how, why) and three auxiliaries (be, do, can) in the third person singular and plural. It was established that the rates of non-inversion errors do not differ by wh-word, auxiliary or number alone. However, they differ by lexical auxiliary subtype and by wh-word + lexical auxiliary combination. It was found to be a source of double marking, even in $d o$-structures (e.g., What does she does like?).

The research (Roesch \& Chondrogianni, 2016) of wh-questions comprehension by early (three- to four-year of age) sequential and simultaneous bilingual children proved the 
general advantage of the simultaneous ones. On the other hand, the similarities of the nature of errors in both groups may be regarded as the proof of universal regularities in the acquisition of the language morphosyntactic features.

Taking into account the discrepancies between the abovementioned studies and the scarcity of the data concerning the EFL learners, we conducted our own investigation into the issue under consideration.

\section{Methods and Techniques of the Research Методи і методики дослідження}

The aim of our research was to compare the wh-questions acquisition by learners of English as a foreign language with the same process in monolinguals and early bilinguals as described above.

We selected 26 subjects distributed among three groups: group $1-11$ adults, factory engineers (age 27-50, period of observation - 10 months, 2 classes (4 hours) a week; group 2-10 schoolchildren (age - 10-12, 2 classes (4 hours) a week, period of observation - 4 months); group 3 - 5 adults, age - 14-40, 2 classes (4 hours) a week, period of observation -7 months.

The elicitation procedure included scrambled sentence technique, question reconstruction, oral interviews, and translation into English.

\section{Results}

\section{Результати}

Like in the first language acquisition (Ingram, 1989; Rowland \& Pine, 2000), our subjects went through the stage of formulaic structures, where they used correct whquestions (beginning with What is, Where is and What colour is) as formulae and could not transfer them to the new situations, where those structures virtually fell apart.

Similar to the first language acquisition (Ingram, 1989; Marcus et al., 1992), we witnessed the phenomenon of overgeneralization, when after the correct use of formulae (e.g. Who works here?), under the impact of the newly introduced structures with do, the subjects started using the same question in the wrong way (e.g. Who does work here?), which signaled the completion of the $d o$-inversion mechanism acquisition.

Archiforms, characteristic of the first language acquisition (Ingram, 1989), were registered in the speech of all subjects at all stages of the foreign language acquisition. The examples of the different varieties of the archiforms are given below.

The use of be instead of do (e.g., Where is you live? or Are you like the party?). 
The use of do/does/did instead of be (e.g., What does he doing?); does instead of did (e.g., When does she came?); did instead of do (e.g., How many letters did you usually write a day?). Similar to the first language acquisition, there were instances of interference among different operators or simultaneous use of several of them (e.g., What are do your friends? Why must I am asking?).

The cases of auxiliary (e.g., Is there on the bookshelves is some the brushes?) and past tense double marking (e.g., Why didn't you went?) registered in the subjects' speech are also typical of the first language acquisition (Ingram, 1989; Ambridge et al., 2006).

The difference between the dynamics of the wh-questions acquisition by monolinguals and natural bilinguals, on the one hand, and learners of English as a foreign language, on the other, seems to be in there is/are structures, which have never been reported as a separate problem in the first language acquisition. However, they turned to be one in the acquisition of English as a foreign language.

In the theory of the first language (Ingram, 1989), it is believed that the attainment of $d o$-inversion is the last stage in the wh-questions acquisition process. However, errors in the wh-questions based on there is/are structures (e.g., How many books on the table?) were registered even after the $d o$-inversion stage was over.

The assumption concerning a special role of there is/are structures in the whquestions acquisition by the learners of English as a foreign language was corroborated by the special test results. In it, the subjects' accuracy exceeded $90 \%$ in all types of whquestions except those based on there is/are structures, where it amounted only to $23 \%$, and in combination with modal verbs - to mere $5 \%$. Because the errors were exclusively related to the omission of there or there is/are, it seems safe to assume a special role of the said structures in the wh-questions acquisition by the learners of English (at least, ten-year olds and over) as a foreign language in a formal environment.

\section{Conclusions \\ Висновки}

Basing on this analysis, we may assume the existence of universal regularities in the English wh-questions acquisition irrespective of the learners' age and the conditions of acquisition (English as the first, second or foreign language, formal or informal learning). On the other hand, the said (as well as many other) factors undoubtedly have their impact on the acquisition process and require additional research. 


\section{References}

Ambridge, B., Rowland, C., Theakston, A., \& Tomasello, M. (2006). Comparing different accounts of inversion errors in children's non-subject wh-questions: 'What experimental data can tell us?'. Journal of Child Language, 33(3), 519-557. https://doi.org/10.1017/S0305000906007513

Contemori, C., Carlson, M., \& Marinis, T. (2018). On-line processing of English which-questions by children and adults: A visual world paradigm study. Journal of Child Language, 45(2), 415-441. https://doi.org/10.1017/S0305000917000277

Ingram, D. (1989). First language acquisition: method, description, and explanation. Cambridge: Cambridge University Press.

Marcus, G.F., Pinker, S., Ullman, M., Hollander, M., Rosen, T.J., \& Xu, F. (1992). Overregularization in language acquisition. Monographs of the Society for Research in Child Development, 57(4), 1-182. https://doi.org/10.2307/1166115

Roesch, A., \& Chondrogianni, V. (2016). "Which mouse kissed the frog?" Effects of age of onset, length of exposure, and knowledge of case marking on the comprehension of wh-questions in German-speaking simultaneous and early sequential bilingual children. Journal of Child Language, 43(3), 635-661. https://doi.org/10.1017/S0305000916000015

Rowland, C., \& Pine, J. (2000). Subject-auxiliary inversion errors and wh-question acquisition: 'what children do know?' Journal of Child Language, 27(1), 157-181. https://doi.org/10.1017/S0305000999004055

Rowland, C., \& Pine, J. (2003). The development of inversion in wh-questions: A reply to Van Valin. Journal of Child Language, 30(1), 197-212. https://doi.org/10.1017/S0305000902005445

Valiant, V., Casey, L. (2003). Young children's acquisition of wh-questions: the role of structured input. Journal of Child Language, 30(1), 117-143. https://doi.org/10.1017/S0305000902005457

Van Valin, R. (2002). The development of subject-auxiliary inversion in English wh-questions: An alternative analysis. Journal of Child Language, 29(1), 161-175. https://doi.org/10.1017/S0305000901004974 